\title{
Effectiveness of Concept Achievement Learning Model with Scientific Approach to Students' Mathematical Communication Skills in Class VIII Function Materials of SMP Negeri 1 Berastagi
}

Efektivitas Model Pembelajaran Pencapaian Konsep dengan Pendekatan Ilmiah terhadap Kemampuan Komunikasi Matematis Siswa pada Materi Fungsi

\begin{tabular}{l}
\hline Author \\
\hline Atania Christianti Br \\
Ginting \\
Universitas Negeri Medan \\
Jl. William Iskandar Ps. V, \\
Kenangan Baru, Kec. Percut Sei \\
Tuan, Kabupaten Deli Serdang, \\
Sumatera Utara 20371 \\
ataniaitink@gmail.com
\end{tabular}

\section{Duconomics} Sci-meet

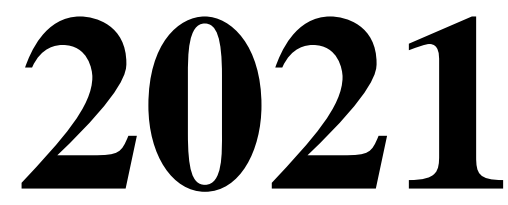

VOLUME 1 JULI

Page

\section{5-71}

DOI

10.37010/duconomics.v1.5404

Corresponding Author

ataniaitink@gmail.com

082165839696
Kelas VIII SMP Negeri 1 Berastagi

Abstract

This study is against the background of low students' mathematical communication skills. This study aims to determine the effectiveness of concept achievement model with scientific approach to students' mathematical communication skills in the function material of grade VIII SMP Negeri 1 Berastagi. This research is a quasi-quantitative research experiment. The sample technique used is cluster random sampling obtained

class VIII-1 as an experimental class. Indicators of learning effectiveness used by

researchers are 1) the quality of learning; 2) the level of learning. This study uses post-test instruments of learning results in the form of essays and observation sheets of

teachers' similar teaching with the learning model used. Based on the regression analysis test obtained the regression equation $Y=16.230+0.783 X$, which means that both variables have a positive linear relationship. For the meaning of the

correlation coefficient of communication ability obtained $t_{\text {table }}=2.04$ and

$t_{\text {count }}=16.368$ which is the $t_{\text {count }}>t_{\text {table }}$. So the testing of the hypothesis of reject $H_{0}$ and $H_{a}$ accepted, then there is a strong and meaningful relationship between the learning model of concept achievement to the mathematical communication skills of students. Then the coefficient of determination obtained $\left(r^{2}\right)=89.93 \%$ means that there is a contribution of concept achievement learning model with scientific approach to the mathematical communication skills of students on function teaching materials by $89.93 \%$ so that based on learning quality indicators, the learning model is said to be effectively used. Based on the results of active observations of teacher activities obtained a total average of 4.26 which means the uniformity of teachers teaching with a model of learning concept achievement with a scientific approach is good and effective to the mathematical communication skills of students

Keywords

Concept Achievement Model, Scientific Approach, Communication skills

Abstrak

Penelitian ini berlatar belakang rendahnya kemampuan komunikasi matematis siswa. Penelitian ini bertujuan untuk mengetahui efektivitas model pencapaian konsep dengan pendekatan ilmiah terhadap kemampuan komunikasi matematis siswa pada materi fungsi kelas VIII SMP Negeri 1 Berastagi. Penelitian ini merupakan penelitian kuantitatif quasi eksperimen. Teknik sampel yang digunakan yaitu cluster random sampling diperoleh kelas VIII-1 sebagai kelas eksperimen. Indikator efektivitas pembelajaran yang digunakan peneliti adalah 1) kualitas pembelajaran; 2) kesesuaian tingkat pembelajaran. Penelitian ini menggunakan instrumen post-tes hasil belajar dalam bentuk essay-test dan lembar observasi kesesuaian guru mengajar dengan model pembelajaran yang digunakan. Berdasarkan uji analisis regresi diperoleh persamaan regresi $Y=16,230+0,783 X$, yang mana artinya kedua variabel mempunyai hubungan linear yang positif. Untuk keberartian koefisien korelasi kemampuan komunikasi diperoleh $t_{\text {tabel }}=2,04$ dan $t_{\text {hitung }}=16,368$ yang mana $t_{\text {hitung }}>t_{\text {tabel }}$. Maka pengujian hipotesis tolak $\mathrm{H}_{0}$ dan $\mathrm{H}_{\mathrm{a}}$ diterima, maka ada hubungan yang kuat dan berarti antara model pembelajaran pencapaian konsep terhadap kemampuan komunikasi matematis siswa. Kemudian koefisien determinasi diperoleh $\left(\mathrm{r}^{2}\right)=89,93 \%$ artinya ada kontribusi model pembelajaran pencapaian konsep dengan pendekatan ilmiah terhadap kemampuan komunikasi matematis siswa pada materi ajar fungsi sebesar $89,93 \%$ sehingga berdasarkan indikator kualitas pembelajaran, model pembelajaran dikatakan efektif digunakan. Berdasarkan dari hasil observasi aktif kegiatan guru diperoleh rata-rata total sebesar 4,26 yang mana berarti kesesuaian guru mengajar dengan model pembelajaran pencapaian konsep dengan pendekatan ilmiah sudah baik dan efektif terhadap kemampuan komunikasi matematis siswa

Kata kunci

Model Pencapaian Konsep, Pendekatan Ilmiah, kemampuan Komunikasi 


\section{PENDAHULUAN}

Pendidikan memiliki peranan yang sangat penting bagi kehidupan suatu bangsa. Karena dengan pendidikan dapat menciptakan potensi anak menjadi generasi yang bermutu. (Trianto,2010) mengatakan bahwa, Pendidikan merupakan upaya yang tepat untuk menyiapkan sumber daya manusia yang berkualitas dan satu-satunya wadah yang dapat dipandang dan selayaknya berfungsi sebagai alat untuk membangun Sumber Daya Manusia (SDM) yang bermutu tinggi (Trianto, 2010). Dalam mencapai tujuan pendidikan nasional pemerintah telah menyelenggarakan berbagai berbagai kebijakan dan perbaikan yang diharapkan mampu meningkatkan mutu pendidikan di berbagai jenis dan jenjang. Salah satunya dalam pendidikan matematika. Matematika adalah salah satu ilmu pengetahuan yang sangat penting baik dalam pendidikan maupun kehidupan sehari-hari. Matematika diberikan pada setiap jenjang pendidikan untuk mempersiapkan siswa dalam menghadapi perkembangan dunia yang semakin maju dan berkembang pesat.

Matematika merupakan ilmu yang dapat digunakan sebagai sarana berpikir ilmiah karena matematika diperlukan untuk mengembangkan kemampuan berpikir logis, sistematis, pemahaman konsep dan mampu mengkomunikasikannya. Sesuai dengan tujuan yang tercantum dalam Kurikulum Tingkat Satuan Pendidikan (KTSP) yang dikeluarkan oleh Permendiknas No. 22 Tahun 2006, bahwa tujuan pembelajaran matematika yaitu: 1) Memahami konsep matematika, 2) Menggunakan penalaran pada pola dan sifat, 3) Memecahkan masalah, 4) Mengkomunikasikan gagasan dengan simbol.

Namun dalam kenyataannya, matematika merupakan mata pelajaran yang kurang diminati oleh siswa. Seperti yang diungkapkan oleh (Wahyudin,2008) bahwa "Matematika merupakan mata pelajaran yang sulit untuk diajarkan maupun dipelajari". Sedangkan (Abdurrahman,2009) mengungkapkan bahwa "dari bidang studi yang diajarkan di sekolah, matematika merupakan bidang studi yang dianggap paling sulit oleh para siswa". Pemikiran bahwa matematika itu merupakan pelajaran yang sulit telah menimbulkan persepsi yang buruk terhadap pelajaran matematika karna siswa cenderung merasa bosan dan malas untuk belajar matematika. Hal ini juga dapat kita lihat melalui rekapitulasi hasil rata-rata nilai UN matematika siswa SMP yang paling rendah bila dibandingkan dengan matapelajaran lain:

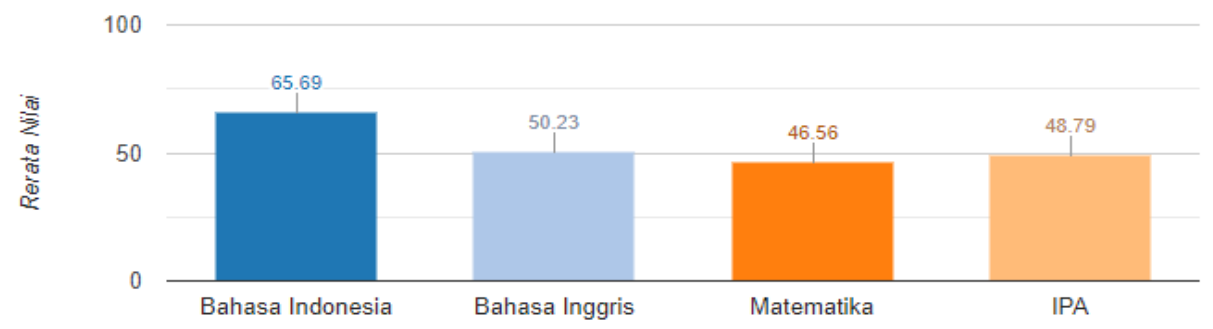

(sumber : https://hasilun.puspendik.kemdikbud.go.id/)

Gambar 1. Grafik Rata-Rata Nilai Ujian Nasional SMP Tahun 2019

Faktor lain yang menyebabkan kualitas pembelajaran matematika rendah disebabkan oleh pembelajaran yang masih bersifat konvensional. Pembelajaran yang dilakukan oleh guru kurang bervariasi dan kurang memacu minat siswa untuk mempelajari lebih dalam suatu materi, guru kurang mendorong siswa untuk menyatakan pemikiran mereka. Hal ini menunjukkan penting adanya kemampuan komunikasi matematis siswa. Dalam (Ansari,2009) matematika sebagai alat komunikasi (mathematics as communication) merupakan pengembangan bahasa dan simbol untuk mengkomunikasikan ide matematika, sehingga siswa dapat: 1) Mengungkapkan dan menjelaskan pemikiran mereka tentang ide matematika dan hubungannya. 2) Mampu Merumuskan defenisi matematika dan membuat generalisasi melalui proses 
penemuan. 3) Mengungkapkan ide matematika secara lisan dan tulisan. 4) Membaca wacana matematika dengan pemahaman. 5) Menjelaskan dan mengajukan serta memperluas peranan terhadap matematika yang telah dipelajarinya. 6) Menghargai keindahan dan notasi matematika, serta perannya dalam mengembangkan ide gagasan matematika. Dengan meningkatkan kemampuan komunikasi bisa membantu pembelajaran siswa tentang konsep matematika ketika mereka memerankan situasi, menggambarkan, menggunakan objek, memberikan laporan dan penjelasan verbal. Kemampuan komunikasi yang baik akan membantu siswa mengkomunikasikan pemahaman yang dimilikinya.

Namun banyaknya siswa yang tidak memahami konsep-konsep matematika yang diajarkan oleh guru dan belum mampu menerapkan rumus dari setiap soal yang diberikan. Padahal pada dasarnya matematika harus memahami konsep. Sering kali siswa cenderung hanya menghapal konsep-konsep matematika sehingga tidak memahami maksud dan isinya. Siswa hanya menerima konsep seperti mengkonsumsi tanpa ada umpan balik yang dapat membuat siswa terus mengingat konsep tersebut.

Oleh karena itu model pembelajaran pencapaian konsep dapat menjadi salah satu solusi yang dapat kita gunakan untuk meningkatkan kemampuan siswa dalam memahami konsep matematika. Menurut (Hamzah,2008) model pembelajaran pencapaian konsep bertujuan untuk membantu siswa memahami suatu konsep tertentu. Sedangkan menurut Joyce dan Weill (Mustamin,2005) "model pembelajaran pencapaian konsep, memberi penguatan dan dorongandorongan internal manusia dalam memahami ilmu pengetahuan, dengan cara menggali, memahami dan mengorganisasikan, serta mengembangkan bahasa untuk mengungkapkannya. Menurut (A. Situmorang \& Tambunan, 2020) Ada tiga cara yang dapat dilakukan oleh guru dalam membimbing aktifitas siswa yaitu:(a) Guru mendorong siswa untuk menyatakan pemikiran mereka dalam bentuk hipotesa, bukan dalam bentuk observasi ; (b) Dalam menetapkan hipotesis diterima atau tidaknya, guru menuntun jalan pikir siswa; (c) Guru memberi kesempatan kepada siswa untuk menjelaskan mengapa mereka menerima atau menolak suatu hipotesis. Penggunaan model pencapaian konsep menghadirkan contoh-contoh yang akrab dan relevan dengan situasi nyata siswa, adapun langkah awal yang dilakukan dimulai dengan pemberian contoh-contoh penerapan konsep yang diajarkan, kemudian akan diturunkan defenisi dari konsep-konsep berdasarkan hasil pengamatan dari contoh yang diberikan. Oleh karena itu dalam penggunaan model ini sangat penting dalam pemilihan contoh yang tepat agar siswa menemukan konsep yang diajarkan. Selain dari pada itu model pencapaian konsep akan dipadukan dengan menggunakan pendekatan ilmiah. Diharapkan pembelajaran akan lebih terarah dan menarik bagi siswa.

Pendekatan ilmiah terkoordinir secara sistematis dan mengarahkan siswa dalam menghadapi fakta-fakta yang relevan dengan kehidupan sehari-hari. Didalam pendekatan ilmiah (Kurikulum 2013) siswa akan melalui tahap-tahap pembelajaran seperti mengamati, mengumpulkan informasi, mengolah informasi, dan mengkomunikasikan, sehingga Pendekatan ilmiah dapat mendorong siswa berfikir secara kritis. Dalam tahapannya akan dilihat seberapa efektif model pembelajaran pencapaian konsep terhadap kemampuan komunikasi matematika siswa. Menurut (Sinambela,2006) pembelajaran dapat dikatakan efektif apabila sudah mampu mencapai sasaran yang diinginkan, baik dari segi tujuan pembelajaran maupun prestasi siswa yang maksimal.

Berdasarkan beberapa permasalahan diatas, maka penulis tertarik melakukan penelitian yang bejudul "Efektivitas Model Pembelajaran Pencapaian Konsep Dengan Pendekatan Ilmiah Terhadap Kemampuan Komunikasi Matematis Siswa Pada Materi Fungsi Kelas VIII SMP Negeri 1 Berastagi “

\section{METODE}


Penelitian ini menggunakan metode penelitian kuantitatif. Penelitian ini termasuk penelitian jenis eksperimental bersifat quasi eksperimen yang bertujuan untuk mengetahui efektivitas model pencapaian konsep dengan pendekatan ilmiah terhadap kemampuan komunikasi matematis siswa pada materi fungsi kelas VIII SMP Negeri 1 Berastagi. Rancangan penelitian menggunakan the one-shot case study. Penelitian ini melibatkan satu kelas eksperimen yang diberikan treatment (perlakuan) dengan model pencapian konsep. Kemudian diadakan post-test dan mengambil kesimpulan

Penelitian ini berlokasi di SMP Negeri 1 Berastagi, yang terletak di kec. Berastagi Kabupaten Karo. Adapun yang menjadi populasinya adalah seluruh siswa kelas VIII SMP Negeri 1 Berastagi yang terdiri dari 9 kelas.Teknik pengambilan sampel pada penelitian ini adalah jenis probability sampling, yaitu Cluster Random Sampling diperoleh kelas VIII-1 sebagai sampel yang terdiri dari 32 siswa.

Untuk melihat efektivitas model pembelajaran, dilihat dari dua indikator, yaitu : 1) Kualitas Pembelajaran, kualitas belajar siswa dilihat berdasarkan hasil belajar siswa. Adapun kriteria kualitas pembelajaran dikatakan sudah baik adalah apabila besar pengaruh dari model pembelajaran terhadap kemampuan yang sudah dicapai lebih besar dari 75\%; 2) Kesesuaian Tingkat Pembelajarn, Kesesuaian tingkat pembelajaran diukur dari lembar observasi kesesuaian guru mengajar dengan model pembelajaran yang digunakan. Berdasarkan kedua indikator tersebut maka adapun teknik pengumpulan data menggunakan instrumen post-tes hasil belajar dalam bentuk essay-test dan lembar observasi kesesuain guru mengajar dengan model pembelajaran yang digunakan. Teknik pengumpulan data yang digunakan disesuaikan dengan prosedur yang sistematis dan standar untuk memperoleh data yang diinginkan. Dalam penerapan insrumen soal test diuji sebelumnya untuk memperoleh kevalidan, reliabel, daya pembeda dan tingkat kesukaran soal.

Selanjutnya data yang diperoleh dianalisis dengan menggunakan program Ms. Excel, untuk memperoleh nilai rata-rata, varians dan simpangan baku. Selanjutnya akan diuji normalitas data. Setelah data normal maka akan dilakukan uji regresi linear sederhana, adapun bentuk persamaan regresinya $\bar{Y}=a+b X$ (Sudjana, 2012). Selanjutnya akan dihitung jumlah kuadrat (JK), uji kelinearan regresi, uji keberartian regresi, koefisien korelasi, uji keberartian koefisien korelasi, dan koefisien determinasi.

Selanjutnya untuk melihat kesesuaian tingkat pebelajaran dianalisis dengan mencari rata-rata skor kemampuan guru mengelola pembelajaran. Hasil observasi kesesuaian tingkat pembelajaran dapat digunakan untuk menyatakan efektivitas apabila rata-rata skor sudah mencapai $4 \leq T K G<5$ (Baik)

\section{HASIL DAN PEMBAHASAN}

Penelitian dilakukan sebanyak 4 pertemuan dengan rincian 3 kali untuk kegiatan pembelajaran, dan satu kali pertemuan untuk kegiatan post-test. Pada pertemuan keempat peneliti memberikan post-test kepada peserta didik untuk mengukur kemampuan komunikasi matematika siswa setelah melakukan treatment (perlakuan) yang menggunakan model pembelajaran pencapaian konsep dengan pendekatan ilmiah sehingga didapat data observasi peserta didik (variabel $\mathrm{X}$ ) dan data post-test mengukur kemampuan komunikasi matematika siswa (variabel Y) yang telah diujikan. Soal post-test yang diberikan telah diuji validitas, reliabilitas,tingkat kesukaran dan daya pembeda antar soal. Soal post-tes yang diujikan sebanyak 5 soal essay kepada 32 responden. Berdasarkan hasil yang diperoleh dari observasi dan nilai post-test siswa diperoleh rata-rata, simpangan baku dan varians. 
Tebel 1. Nilai Rata-Rata, Simpangan Baku, Varians Dari Data Observasi Dan Nilai Post-Test

\begin{tabular}{|c|c|c|}
\hline Parameter & X & Y \\
\hline N & 32 & 32 \\
\hline Rata-rata & 76,718 & 76,312 \\
\hline Varians & 194,531 & 132,673 \\
\hline Simpangan Baku & 13,947 & 11,518 \\
\hline
\end{tabular}

Selanjutnya dilakukan analisis statistik data untuk mengetahui perbedaan kedua kelompok tersebut signifikan atau tidak. Adapun langkah selanjutnya adalah dengan menguji normalitas menggunakan uji lilifors. Dari hasil uji normalitas data observasi model pembelajaran pencapaian konsep dengan pendekatan ilmiah diperoleh $L_{\text {hitung }}=0,1201<$ $L_{\text {tabel }}=0,156$ hal ini menunjukkan bahwa sampel berasal dari populasi yang berdistribusi normal. Dari uji normalitas nilai post-test kemampuan komunikasi matematis siswa diperoleh $L_{\text {hitung }}=0,1108<L_{\text {tabel }}=0,156$, hal ini menunjukkan bahwa data post-test terhadap kemampuan komunikasi matematika siswa berdistribusi normal. Karena data berdistribusi normal maka dilakukan uji regresi sederhana.

Untuk persamaan regresi diperoleh nilai $a=16,230$ dan nilai $b=0,783$ sehingga persamaan regresinya $\hat{Y}=16,230+0,783 X$. Pada persamaan tersebut koefisien arah regresi linier $b$ positif artinya kedua variabel mempunyai hubungan linear yang positif. Untuk mengetahui persamaan regresi diatas linear dan ada keberartian atau tidak dilakukan uji signifikansi dan linearitas regresi dengan analisis varians. Adapun rangkuman hasil perhitungan uji signifikansi dapat dilihat pada tabel :

Tabel 2. Hasil Perhitungan ANAVA

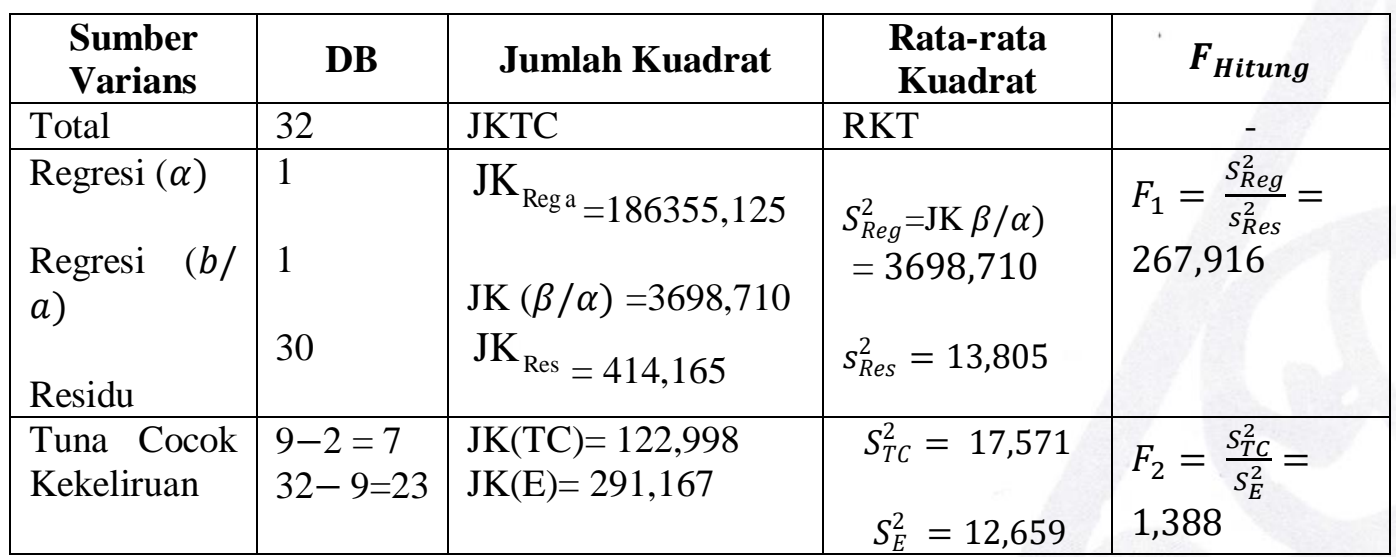

Keterangan

(Sudjana ,2012)

Kelinearan regresi $\left(F_{\text {hitung }}=1,388<F_{\text {tabel }}=2,45\right)$

Keberartian regresi $\left(F_{\text {hitung }}=267,91>F_{\text {tabel }}=4,17\right)$

Dari tabel diatas disimpulkan bahwa model pembelajaran pencapaian konsep dengan pendekatan ilmiah terhadap kemampuan komunikasi siswa terdapat keberartian dan linear. Selanjutnya dilakukan pengujian koefisien korelasi menggunakan rumus produc moment . dari hasil perhitungan diperoleh $r_{x y}=0,948$. Uji keberartian koefisien korelasi dengan uji t dengan taraf signifikan $a=0,05$ diperoleh $t_{\text {hitung }}=16,368>t_{\text {tabel }}=2,04$, hal ini menunjukkan 
bahwa ada hubungan yang linear dan berarti antara model pembelajaran pencapaian konsep dengan pendekatan ilmiah terhadap kemampuan komunikasi matematis siswa.

Untuk mengetahui seberapa besar pengaruh variabel X (Model pembelajaran) terhadap variabel Y ( kemampuan komunikasi) digunakan koefisien determinasi. Adapun perolehan hasil koefisien determinasi $\left(r^{2}\right)=0,8993$ atau sebesar $89,93 \%$ artinya ada kontribusi model pembelajaran pencapaian konsep dengan pendekatan ilmiah terhadap kemampuan komunikasi matematis siswa pada materi ajar fungsi sebesar $89,93 \%$ sehingga berdasarkan indikator kualitas pembelajaran, model pembelajaran dikatakan efektif digunakan.

Selanjutnya untuk mengetahui kesesuaian tingkat pembelajaran dilakukan observasi kesesuaian guru mengajar dengan model pembelajaran yang digunakan. Adapun perolehan rata-rata total dari tiga orang observatory adalah sebesar $\bar{X}=4,267$. Berdasarkan klasifikasi tingkat kemampuan guru maka dapat dilihat efektivitas kesesuaian tingkat pembelajaran sudah baik karena berada diantara $4 \leq T K G<5$ atau $4 \leq 4,267<5$.

Dengan model pembelajaran pencapian konsep dengan pendekatan ilmiah telah di desain dengan baik serta dijalankan sesuai dengan semestinya maka akan memperoleh hasil yang efektif bagi hasil belajar siswa, khususnya dalam mengukur kemampuan komunikasi matematis siswa. Karena dalam penerapannya diharapkan siswa mampu memahami konsepkonsep matematika yang dipelajari sehingga siswa mampu mengembangkannya. Bila siswa memahami konsep maka sejalan dengan kemampuan komunikasi dimana siswa mampu memaparkan ide-ide atau gagasan yang mereka miliki.

\section{PENUTUP}

Dari analisis data dan pengujian hipotesis di dapat bahwa kualitas pembelajaran sudah baik dimana besar pengaruhnya sebesar $89,93 \%$ dan interpretasi kesesuaian tingkat pembelajaran yang dilakukan guru tergolong baik, maka sebagai kesimpulan dalam penelitian ini adalah model pembelajaran pencapaian konsep dengan pendekatan ilmiah efektif terhadap kemampuan komunikasi matematis siswa pada materi fungsi kelas VIII SMP Negeri 1 Berastagi. Diharapkan model pembelajaran pencapaian konsep dengan pendekata ilmiah dapat efektif juga digunakan untuk mengukur kemampuan matematis baik dalam materi fungsi maupun menggunakan materi matematika lainnya.

\section{DAFTAR PUSTAKA}

Abdurrahman, Mulyono. (2009). Pendidikan Bagi Anak Berkesulitan Belajar. Cetakan Ii. Jakarta: Rineka Cipta.

Ansari. I.B. (2009). Komunikasi Matematika Konsep Dan Aplikasi. Banda Aceh: Yayasan Pena. BSNP. 2006. Kurikulum Tingkat Satuan Pendidikan (KTSP). Jakarta: Departemen Pendidikan Nasional

Hamzah, B. Uno. (2008). Model Pembelajaran. Cetakan Iii. Jakarta : Bumi Aksara

Kemendikbud. (2019). Data Hasil Ujian Nasional. [Online] Tersedia: : https://hasilun.puspendik.kemdikbud.go.id/

Kemendikbud. 2013. Pendekatan Scientific (Ilmiah) dalam Pembelajaran. Jakarta: Pusbang Prodik

Mustamin, Anggo. (2005). Pembelajaran Matematika menggunakan model pembelajaran Pencapian Konsep. Wakapendik: Lembaga Kajian Pengembangan Pendidikan Universitas Haluoleo. Hal 72

Sinambela. 2006. Konsep dan Makna Pembelajaran. Jakarta: PT. Rineka Cipta. 
Situmorang, A.S \& Hardi Tambunan.(2020). Model Pencapaian Konsep Dengan Pendekata Ilmiah Terhadap Kemampuan Representative Mahasiswa Prodi Pendidikan Matemataika Fkip Uhn. Serpen: Journal Of Mathematics Education And Applied. Vol 01, No. 02. 1-7. Medan : Universitas Hkbp Nommensen

Situmorang, Adi S. (2019). Desain Model Pencapaian Konsep Terhadap Minat Belajar Mahasiswa Fkip Uhn. Jurnal Penelitian Bidang Pendidikan Unimed: 25(1) https://jurnal.unimed.ac.id/2012/index.php/penelitian/issue/archiv

Sudjana. (2012). Metode Statistika. Bandung: Tarsito.

Trianto. (2010). Mendesain Model Pembelajaran Inovatif-Progresif. Jakarta: Kencana Prenada Media Group

Wahyudin. (2008). Pembelajaran Dan Model-Model Pembelajaran. Jakarta : Cv. Ipa Abong. 